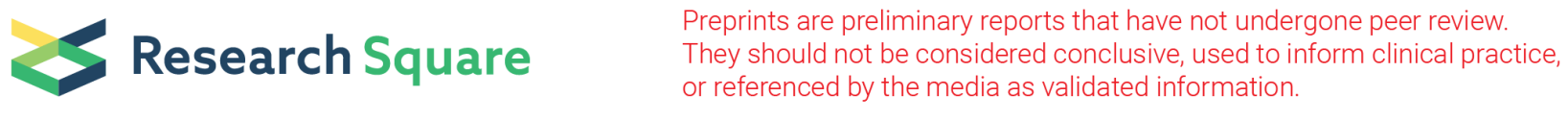

Preprints are preliminary reports that have not undergone peer review. or referenced by the media as validated information.

\title{
Assessment of Genetic Variation in COI Gene of Horseshoe Crab (Tachypleus Gigas) Population Along the Coast of the Bay of Bengal in Odisha, India
}

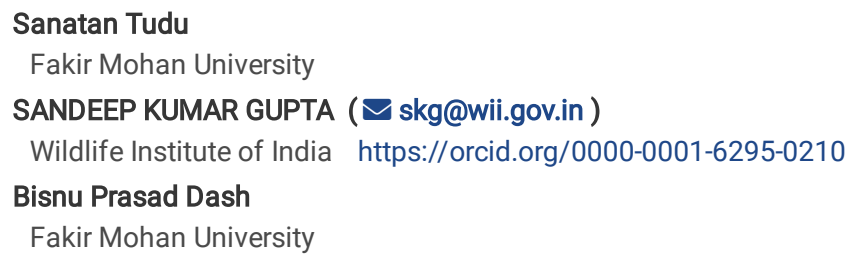




\section{Abstract}

Horseshoe crab (Tachypleus gigas) is an archaic group of marine creature which plays a vital role in the saline ecosystem. Many researchers emphasize and enhance the knowledge about the horseshoe crab's basic biology, morphology, and ecology, whereas very little information is available about its population genetics. We attempted to develop a baseline database about the ecology, phylogeography, and genetic variation among the horseshoe crab population from Odisha, India. We collected 152 samples of horseshoe crab from the coastal area of the Bay of Bengal. The generated Cytochrome $\mathrm{C}$ Oxidase Subunit / gene ( $\mathrm{CO} /$ sequences of $T$. gigas were compared with the sequences of $T$. gigas obtained from GenBank. The GenBank sequences were of two populations from South China and Malaysia. A total of 26 unique haplotypes were observed in three populations of T. gigas. Pairwise F-statistic distance $\left(F_{S T}\right)$ between South China-India was 0.708; Malaysia-India was 0.608 , and South China-Malaysia was 0.136 . It indicated that the South China population was closely related to the Malaysian population and the Indian population was appeared to be genetically distinct from the other two populations. It signifies the ecological importance of the Indian population. Furthermore, the migrant per generation ( $\mathrm{Nm}$ ) was 0.16 , which indicated a low gene flow among T. gigas populations. The haplotype diversity $(\mathrm{Hd})$ and nucleotide diversity $(\pi)$ were 0.58826 and 0.00476 , respectively. This study would help lay future strategy and conservation of horseshoe crab across the Bay of Bengal.

\section{Introduction}

Horseshoe crabs are one of the archaic groups of marine organisms with significant economic value and scientific significance. These animals play an important role in both marine and estuarine ecosystems. Four existing species of horseshoe crabs are reported throughout the world. Of these, Limulus polyphemus [1] is found on North America Atlantic coast, whereas other three species of horseshoe crabs like Tachypleus gigas [2], Tachypleus tridentatus [3] and Carcinoscorpius rotundicauda [4] are found in the Asian countries ranging from $6^{\circ} \mathrm{S}$ to $31^{\circ} \mathrm{N}$ and between $90^{\circ} \mathrm{E}$ and $118^{\circ} \mathrm{E}$ [5]. Out of the four horseshoe crab species, Tachypleus gigas and Carcinoscorpius rotundicauda have been reported with overlapping distribution in many regions in the Bay of Bengal, India and South China Sea [6,7]. Tachypleus gigas prefer sandy areas and C. rotundicauda is found in muddy regions [8-12]. However, trispine Asian horseshoe crab Tachypleus tridentatus have a preference to occur in the coastal zone of shallow water in southern China ranges from Vietnam to Japan. In the Indian sub-continent, the maximum numbers of horseshoe crabs are distributed along the Bay of Bengal coast of India, ranging from Sundarban mangrove forest of West Bengal state to Dhamara of Odisha state [13,14]. In Odisha state, the coastal region of the Balasore district is richly populated with horseshoe crabs. Horseshoe crab inhabits three regions like the coastal bay, intertidal mud zone or sand flat zone, and deepwater regions [15]. Balasore has qualified as a preferable place for breeding due to the intertidal zone, which helps for their spawning activity [10]. It has been reported that the T. gigas and C. rotundicauda come to the estuary for spawning purposes in pairs during the tidal movement of spring seasons in India [16,17]. The population of horseshoe crabs is declining rapidly due to overfishing, water pollution, habitat destruction, resulting in reduced abundance and quality of prey available as a food source to horseshoe crab [6]. Hence, it is well accepted and considered an endangered marine organism in India and other regions [18-20]. Several controversies have been raised among the evolutionary biologist about the horseshoe crab phylogeny from the last several years. They are often considered the foremost example of long-term survival in marine. These marine organisms still retain their body morphology and stable genetic structure over millions of years [ 21-23], hence called as 'Living fossil' [24], 'Phylogenetic relict' [25] and becoming endangered marine animals. Generally, in the marine ecosystem, organisms exhibit strong gene flow for their dissemination activity across the spacious geographic ranges [26]. Some habitually display a low level of genetic differentiation for their incapability of long-distance dispersal over the large geographic scale [27]. Horseshoe crabs are lean migratory animals that are probable to have subdivisions population on a small geographic scale [26, 28]. They reveal a low level of genetic diversity throughout their entire evolutionary history. The allozyme [25,29], restriction fragment length polymorphism (RFLP) of mtDNA [30], and microsatellite analysis [31] revealed that the population of American horseshoe crabs (Limulus polyphemus) was genetically distinct in the Gulf of Mexico and the Atlantic coast. In a small geographic range of North America, limited gene flow was observed through $\mathrm{CO} /$ gene analysis [28]. Two genetic groups were detected based on the distribution of haplotypes and the significant genetic structure of Japanese horseshoe crabs (T. tridentatus) populations by the mtDNA AT-rich region [32]. A few research studies have been conducted to explore the phylogeny and phylogeography of four extant species using various molecular methods. However, very little knowledge is available about the horseshoe crab's population genetics diversity along the Bay of Bengal coast in India. A molecular study is a powerful tool for investigating genetic differentiation and it has widely been used to determine population genetics, phylogeography and genetic structure. It possesses a rapid rate of evolution, lack of recombination, and maternal inheritance [33]. Mitochondrial Cytochrome C Oxidase subunit I (CO/) is often considered a conserved region and used as a robust marker for the invertibrates and marine species due to a high degree of polymorphism leading to population subdivisions (Hu et al. 2009)[34]. The objective of this study was to examine molecular variations, genetic diversity and historical demography of Indian horseshoe crab in the select area of the Bay of Bengal coast.

\section{Materials And Methodology}

\subsection{Sample collection and DNA extraction}

We collected 152 tissue samples from the dead remains of horseshoe crabs from fourteen sampling sites of the coastal areas of the Bay of Bengal (Table 1). Samples were stored at $-20^{\circ} \mathrm{C}$ in $70 \%$ ethanol for molecular analysis. Genomic DNA was extracted from the tissue sample using the standard Proteinase $\mathrm{K}$ digestion/phenol-chloroform method [35], and a standardized protocol was adopted to extract DNA [36]. The extracted DNA was quantified in a QIAxpert spectrophotometer. Isolated DNAs were diluted in a final concentration of 40-50 ng/ $\mu \mathrm{l}$ for PCR amplification and stored at $4^{\circ} \mathrm{C}$.

\subsection{PCR amplification and sequencing}

We used conserved primers for PCR amplification and sequencing of the mtDNA CO/gene [37]. The total $20 \mu l$ reaction volumes were prepared for PCR reactions using $1 \times$ PCR buffer ( $10 \mathrm{mMTris}-\mathrm{HCl}$, pH 8.3,and $50 \mathrm{mM} \mathrm{KCl}), 1.5 \mathrm{mM} \mathrm{MgCl}, 1 \times \mathrm{BSA}, 0.2 \mathrm{mM}$ of each dNTPs,3 pmol of each primer, 0.5 units of 
DreamTaq DNA Polymerase (Thermo Fisher) and $1 \mu \mathrm{l}(\sim 30 \mathrm{ng})$ of template DNA. The PCR conditions were initial denaturation at $95^{\circ} \mathrm{C}$ for 5 minutes and $95^{\circ} \mathrm{C}$ for the $40 \mathrm{~s}$, annealing temperature at $45^{\circ} \mathrm{Cfor} 50 \mathrm{~s}, 72^{\circ} \mathrm{C}$ for $50 \mathrm{~s}$ followed by 5 cycles and second denaturation at $95^{\circ} \mathrm{C}$ for $40 \mathrm{~s}$, annealing at $51^{\circ} \mathrm{C}$ for $50 \mathrm{~s}$ and extension at $72{ }^{\circ} \mathrm{C}$ for $50 \mathrm{~s}$. The final extension was at $72{ }^{\circ} \mathrm{C}$ for $10 \mathrm{~min}$, followed by 35 cycles, and maintained at $4{ }^{\circ} \mathrm{C}$ until further use. For avoiding any cross-contamination, efficiency, and reliability, control and the negative reaction were taken during DNA extraction and PCR reactions. The PCR amplification was confirmed by electrophoresis on $2 \%$ Agarose gel stained with safe stain dye $(0.5 \mathrm{mg} / \mathrm{ml})$ and visualized under a UV transilluminator. The exonuclease-I and shrimp alkaline phosphatase (Thermo Scientific) was treated at $37^{\circ} \mathrm{C}$ for 20 min, followed by $85^{\circ} \mathrm{C}$ for 15 min with the amplified PCR product to obtained intact DNA. The sequencing was performed from forward and reverse direction using BigDye v3.1 Kit in 3500 XL Genetic Analyzer (Applied Biosystems).

\subsection{Data alignment and molecular analysis}

The obtained DNA sequences were scrutinized for similarity and retrieved through BLAST sequences accessible from NCBI GenBank. Later the sequences were aligned by using Clustal $X$ available in the BioEdit packages [38]. The IUPAC nucleotide was clean in BioEdit software. The numbers of variable sites and population diversity were analyzed using DNASP. A percentage similarity matrix and pairwise distance matrix were generated using MEGA X [39]. Evolutionary analyses were conducted in MEGA X. The haplotype median-joining network was generated by Network v.5.0.0.0 as well as PopArt software. In ARLEQUIN v3.11 software analysis of molecular variance (AMOVA), Tajima's $D$ parameter estimations, gene flow, and mismatch distributions were estimated. Neighbour Joining, Maximum Parsimony and Maximum Likelihood tree were constructed based on 581 bp of the mitochondrial DNA CO/gene

from T. gigas, and three out-group sequences of horseshoe crabs were derived from GenBank. Two different methods, maximum likelihood (ML) and Bayesian inference (BI) were adopted for phylogenetic analysis. In RAxML-VI v.7.0.0. Software analysis ML tree estimation was performed [40]. A Bayesian phylogenetic tree was generated in the beast. Based on the average haplotype diversity, genetic diversity ( $\pi$ ) was estimated. Population pairwise nucleotide differences and their statistical significance were checked using Arlequin v.3.5.1.2 with 10,000 permutations. Geographical distribution and genetic differentiation of the haplotype population within the species were calculated by using PopArt software.

\subsection{Divergence time estimation}

The updated version BEAST v.1.7.5. was used for estimation of divergence among the horseshoe crabs species [41]. The single CO/gene sequence of each species is considered for analysis. We took T. gigas from the Bay of Bengal coast and another from the South China Sea, expecting a genetic gap in both the population for the large geographic distance. The remaining three species, namely L. polyphemus was from Mexico, $T$. tridentatus from the China Sea, $C$. rotundicauda from South Korea, for divergence estimates. The best model HKY was selected for this analysis from the JModel test and the base frequencies were not considered for estimation. We also took equal to empirical values. It was expected to evolve a phylogenetic tree with Yule speciation tree priors and a log-normal uncorrelated tranquil clock [42]. For all these analyses, 25 million generations made for a run. With the help of Tracer v.1.5, the Estimated Sample size (ESS-500) was checked and calculate the value in between the 200-600 ranges of all parameters [40]. We calibrated our tree with the divergence times described by Obst et al. (2012) [43]. According to Fisher [21] the divergence years of Limulidae-Tachyplenae were approximately about 150-130 Mya. The tree was calibrated with the value 140 Mya with a Standard deviation of 10 Mya.

\section{Result}

\subsection{Molecular genetic diversity}

We obtained 581 bp CO/gene sequence from 161 biological samples, of these 319 sites were constant and 34 were variable. We detected 26 distinct CO / mtDNA haplotypes with haplotype diversity $(\mathrm{Hd}) 0.6614$, which occupied $5.852 \%$ of all analyzed sites, including 20 singletons and 14 parsimoniously informative sites (GenBank accession numbers MZ262422-MZ262447). It was also observed that there were 25 transitions, 13 transversions, or inversions/deletions. The estimated Transition/Transversion bias $(R)$ was 1.94 . The frequencies of nucleotide were $\mathrm{A}=9.17 \%, \mathrm{~T}=42.92 \%, \mathrm{C}=24.56 \%$, and $\mathrm{G}$ $=23.36 \%$. For estimating ML values, a tree topology was automatically computed. The maximum Log-likelihood for this computation was -746.630 . Codon positions included were $1 \mathrm{st}+2 \mathrm{nd}+3 \mathrm{rd}+$ Noncoding. All positions containing gaps and missing data were eliminated (complete deletion option). Total 161 individual sequences were categorized into three populations as an Indian, Malaysian, and South China of T. gigas. Pairwise F-statistic distance ( $\left.F_{S T}\right)$ between South China-India was 0.708 ; Malaysia-India was 0.608 , and South China-Malaysia was 0.136 . We also confirmed the intraspecies genetic distance, ranging from 0.00 to 0.05 , while inter-species distance varied from 0.06 to 0.08 for the species under study. The highest distance was observed between T. gigas and L. polyphemus.

\subsection{Genetic variation and haplotype diversity}

To estimates the diversity indices, we used only the $\mathrm{COI}$ gene for molecular analysis. We detected two major haplotypes (H2 and H3) distributed in all sampling sites, while some local haplotypes were specific to the particular sites. Molecular diversity index such as haplotype (h) and nucleotide ( $\pi$ ) diversity was estimated among the horseshoe crab's population in the Bay of Bengal. Nucleotide ( $\pi$ ) and haplotype (h) diversity were found 0.00 to 0.00059 and 0.00 to 0.534 , respectively. Overall nucleotide diversity and haplotype diversity in the Indian horseshoe crab population in the Bay of Bengal was 0.00265 and 0.578 , respectively. We compared mtDNA genetic variation in the Indian horseshoe crab population in the Bay of Bengal with other Tachypleus gigas (South Chinese and Malaysian) populations across its distribution range. We found that Indian horseshoe crab has a comparatively lower level of genetic variation $(h=4, s=3$, mean pairwise difference $=1.53$ ) than the well-connected populations of South China and Malaysia.

\subsection{Historical demography}


The selective neutrality test was taken to confirm population expansion Fu and Li's, Tajima's $D$, and Fu's statistics. The whole data set was included for this analysis. This analysis reveals that Tajima's $D$ was $-2.27032(P<0.01)$, Fu and Li's was $-4.736415(P<0.02)$, while Fu's $F s$ value was $-22.25092(P<0.05)$. Our data suggest that the T. gigas has experienced a sudden demographic expansion. In the mismatch distribution, a smooth and unimodal curve (Fig. 2) was observed among the fourteen geographic populations. The analysis of mismatch distribution was consistent with Fu's Fs statistical test for the population expansion model.

\subsection{Phylogenetic analysis}

Based on the partial sequence mtDNA CO/gene, the phylogenetic tree was established. The best model was also considered as GTR+I from the JModel test. Only T. gigas species were included in the time of phylogenetic analysis. 17 unique haplotypes were obtained from 152 samples. These 17 haplotypes and ten sequences of T. gigas from NCBI GenBank were included for phylogenetic analysis. Interestingly our sample data categorized into two major subpopulations. 11 haplotypes fall under one subpopulation and the remaining six were in another group. In contrast, these were believed a sister group relationship with each other. Each phylogenetic partition was significantly different from one another $(\mathrm{P}<0.01)$. Its overall analysis yielded constant phylogeny. In our study, open and highly supported the connection between Tachypleus gigas and Tachypleus tridentatus was observed than the $C$. rotundicauda, which showed sister taxon relationship, i.e., monophyletic genus Tachypleus. It was also strongly supported for Tachypleinae [44] between Tachypleus and $C$. rotundicauda to establishing phylogenetic clade as a monophyletic relationship.

\subsection{Divergence time estimates}

We obtained 150-130 Mya divergence between Limulidae-Tachypleinae. The diversification of Asian horseshoe crab Tachypleinae occurred during 50 Mya (22-90 Mya), and Tachypleus genus was originated in 36 Mya (14-65), while the internal split of the T. gigas across the South China-Indian was dated to 6 Mya (2-15), shown in Fig. 2.

\section{Discussion}

The marine biodiversity crisis has increased due to heavy anthropogenic activity and resulted in the depletion of habitats for marine organisms. Some of them have got extinct without our knowledge or ever having registered their existence. To assess the divergence time, genetic differentiation, phylogeographic pattern, and genetic structure of the horseshoe crab populations, we used the mtDNA gene (CO/) for molecular analysis. Our finding was congruent with a previous study [45], which displayed the morpho-static structure of horseshoe crabs due to the lack of variation in molecular genetics. Horseshoe crab species showed a slow divergence rate compared to other arthropods [46] due to their long generation time and sexual maturity after ten years [47]. We included three major T. gigas populations such as India, South China and Malaysia. The South China population was closely related to the Malaysian population, and the Indian population was appeared to be genetically distinct from the other two. It can be explained due to its least dispersal capability in the marine ecosystem [26]. We confirmed the intraspecies genetic distance ranged from 0.00 to 0.05 while inter-species distance varied from 0.06 to 0.08 . The highest genetic distance was observed between T. gigas and L. polyphemus. The L. polyphemus was restricted in the Gulf of America and the Atlantic coast only. It showed different genetic appearances. Due to this characteristic, the geographical barrier played an important role in dividing the genetic break for which they may not participate in genetic exchange and the species. The changes in sea level are the major factors to acclimatize/adapted the species to the particular environment resulting in genetic diversity. Hence, we can assume that they are pretty far from the genetic distinct of this species. We also conclude that the Indian horseshoe crab has a comparatively lower level of genetic variation $(h=4, s=3$, mean pairwise difference $=1.53$ ) than the well-connected populations of South China and Malaysia. But it was quite similar to the geographically distinct populations. Therefore, it might also be possible that the Indian horseshoe crab population's isolation due to habitat subdivision was the probable reason for lower genetic variations. It suggested significant population genetic differentiation throughout the range of $T$. gigas along the coast of the Bay of Bengal. Among the 26 haplotypes, the major two $\mathrm{H} 2$ and $\mathrm{H} 3$ dominating subpopulations were observed on the Bengal coast. The haplotypes $\mathrm{H} 13, \mathrm{H} 26, \mathrm{H} 27, \mathrm{H} 16$ and $\mathrm{H} 21$ were one mutation away from the $\mathrm{H} 2$ haplotype and the rest $\mathrm{H} 18, \mathrm{H} 22, \mathrm{H} 17, \mathrm{H} 20, \mathrm{H} 19, \mathrm{H} 23, \mathrm{H} 25, \mathrm{H} 15$ and $\mathrm{H} 24$ were also one mutation away of $\mathrm{H} 3$ haplotype that means other haplotypes are just ancestor of both haplotypes. This analysis revealed that Tajima's $D$ was $-2.27032(P<0.01)$, Fu and Li's was $-4.736415(P<0.02)$ while Fu's Fs value was - $22.25092(P<0.05)$. Our data suggested that the $T$. gigas has experienced a sudden demographic expansion. In the mismatch distribution, a smooth and unimodal curve was observed among the 14 geographic populations. About $65-23$ Mya during the Paleogene era, the Asian horseshoe crabs were diversified and split. Our results strongly supported the previous studies in which it was mentioned that the American species $L$. polyphemus was the sister taxon of three Asian species $[21,45,48]$ and the Asian species was diversified around 55 Mya. As a first Asian species, $C$. rotundicauda (South Korean) was split approximately $50(80-20)$ Mya. T. gigas showed a closer genetic distance with $T$. tridentatus than the $C$. rotundicauda. The Indian and South China species (T. gigas) divergence occurs during15-2 Mya. T. tridentatus has diverged in around 65 - 15 Mya. Although, $C$. rotundicauda has a contrasting pattern of connectivity with $T$. gigas, which can reproduce its isolated lineage. The diversification of Asian horseshoe crab occurred during the Paleocene era (65-23 Mya). We confirmed two distinct horseshoe crab (T. gigas) subpopulations along the Bay of Bengal Bay in India.

The molecular analysis and evolutionary relationship among the Indian horseshoe crab (T. gigas) species significantly displayed a more distinct population. Additionally, in the phylogenetic tree, the genetic relationship of Tachypleus gigas is extreme nearer to Tachypleus tridentatus other than the Carcinoscorpius rotundicauda species. Within the T. gigas species of India and Southeast Asian populations, a restricted gene flow was observed. Interestingly, in the horseshoe crab population of India and the Southeast Asian population, a limited gene flow was observed. However, more detail and further scientific analysis are required to investigate and establish the genetic structure and the evolutionary history of the Indian Horseshoe crab population. An advanced molecular technique should be adapted to conserve valuable marine organisms. The Indian horseshoe crab was geographically distributed in a limited area on the Bay of Bengal coast, but now the current status is under severe exhaustion across all over its range even species is 
vanishing in many estuaries. Due to anthropogenic activities, seawater pollution, overfishing and coastal development caused the loss of habitat vegetation. Accordingly, suitable conservation strategies should be adopted to protect the species and its habitats from extinction.

\section{Declarations}

\section{Acknowledgment}

This study was supported from University Grants Commission Bahadurshah Zafar Marg New Delhi - 110002SA-III. Award no- F1-17.1/2014-15-RGNF-STORI-75893/ (SA III/Website). We thank the Director and Dean, WII and Vice-Chancellor, Fakir Mohan University, Balasore for their kind support. We acknowledge the Divisional Forest Officer, Balasore Wildlife Division and Odisha State Forest Department for providing permission and support.

\section{Author Contributions}

BPD and SKG acquired resources and permission to collect biological samples and developed the concept and designed the framework. ST collected the biological samples and carried out sequencing. ST and SKG performed data analysis and wrote the paper. BPD and SKG finalized the manuscript. All the authors approved the final version of the manuscript

\section{Disclosure statement}

Competing Interests: The authors declare no competing interests

Funding: This study was funded by the University Grants Commission.

\section{Availability of data and material}

The sequence data is submitted to GenBank under Accession No. MZ262422- MZ262447.

Ethical statement: The study was conducted using a tissue collected from the naturally dead animal and therefore, no Institutional Animal Ethics Committee approval was required.

\section{Consent to Participate (Ethics)}

Since the experiment was not conducted on humans, no consent to participate was required.

\section{Consent to Publish (Ethics)}

This study has not used any secondary data for publication, hence no consent to publish was required.

\section{References}

1. Linnaeus C (1758) Systema Naturae per Regna TriaNaturae, Secundum Classes, Ordines, Genera, Species, cum Characteribus, Differentiis, Synonymis, Locis. Vol. 1, Edn. 10. Reformata. LaurentiiSalvii, Holmiae, Stockholm

2. Müller OF. Thiele FW (1785) Entomostraca seu insectatestacea, quae in aquis Daniae et Norvegiaereperit, descripsit et iconibusillustravit Otho Fridericus Müller. Lipsiae \& Havniae [Leipzig \& Copenhagen]

3. Leach WE (1819) Entomostraca. Dictionnaire des Sciences Naturelles. Vol. 14.Levrault et Schoell, Paris

4. Latreille PA (1802) Histoire naturelle, générale et particulière des crustacés et des insectes: ouvragefaisant suite aux oeuvres de Leclerc de Buffon, et Partie du CoursCompletd'HistoireNaturelleRédigé par C.S. Sonnini. F. Dufart, Paris, pp 1-20

5. Sekiguchi K, Shuster CN (2009) Basic habitat requirements of the extant species of horseshoe crabs. In: Biology and Conservation of Horseshoe Crabs. Springer, New York, pp 5-24

6. Sekiguchi K (1988) Biology of Horseshoe Crabs. Science House Press, Tokyo

7. Mishra JK (2009) "Horseshoe crabs, their eco-biological status along the northeast coast of India and the necessity for ecological conservation. In: " in Biology and Conservation of Horseshoe Crabs. Springer, New York, pp 89-96

8. Anderson LI, Shuster CN (2003) Throughout geologic time: where have they lived? The American horseshoe crab. Harvard University Press, Cambridge, pp 189-223

9. Lee CN, Morton B (2005) Experimentally derived estimates of growth by juvenile Tachypleus tridentatus and Carcinoscorpius rotundicauda (Xiphosura) from nursery beaches in Hong Kong. J Exp Mar Biol Ecol 318:39-49. DOI:10.1016/j.jembe.2004.12.010

10. Brockmann HJ, Smith MD (2009) Reproductive competition and sexual selection in horseshoe crabs. Biology and Conservation of Horseshoe Crabs. Springer, New York, pp 610-620

11. Seino S (2009) Conservation planning for endangered species of horseshoe crab in terms of geomorphology of habitats and life history. In: Biology and Conservation of Horseshoe Crabs. Springer, New York, p 634

12. Nelson BR, Behara S, Zhong JMH, Shaharom F, Mithun S, Chatterji A (2015) Episodic human activities and seasonal impacts on the Tachypleus gigas (Müller 1785) population at Tanjung Selangor at Peninsular Malaysia. Estuarine Coastal Shelf Sci 164:313-323

Page 5/10 
13. Chatterji A, Parulekar AH (1992) Fecundity of the Indian horse-shoe crab, Carcinoscorpius rotundicauda (Latreille). Trop Ecol 33:97-102

14. Debnath R, Choudhury A (1989) Geographic distribution of Indian horseshoe crabs (Merostomata: Xiphosura) in the coastal water of Bay of Bengal, India. Journal of Bengal Natural History Society New Series 8:30-35

15. Emily S (2011) Gonads, Size, and Sex Distribution in Juveniles Horseshoe Crabs. Worchester Polytechnic Institute, Massachusetts

16. Chatterji A, Rathod V, Parulekar AH (1992) Spawning migration of the horseshoe crab, Tachypleus gigas (Müller), in relation to lunar cycle. Asian Fish Sci 5:123-128

17. Behera S, Tripathy B, Sivakumar K, Choudhury BC, Bhadury P (2015) Distribution and abundance of two sympatric species of horseshoe crabs along the Odisha coast, India. In: Changing Global Perspectives on Horseshoe Crab Biology, Conservation and Management. Springer, New York, pp 181-191

18. Tanacredi JT, Botton ML, Smith DR (eds) (2009) Biology and conservation of horseshoe crabs

19. Carmichael RH, Botton ML, Shin PKS, Cheung SG (eds) (2015) Changing global perspectives on horseshoe crab biology, conservation and management. Springer, Cham

20. John BA, Nelson BR, Sheikh HI, Cheung SG, Wardiatno Y, Dash BP, Tsuchiya K, Iwasaki Y, Pati S (2018) A review on fisheries and conservation status of Asian horseshoe crabs. Biodivers Conserv 27:3573-3598

21. Fisher DC (1984) The Xiphosurida: archetypes or bradytely? In: Eldredge N, Stanley SM (eds) Living Fossils. Springer, Berlin, pp $106-212$

22. John BA, Jalal KCA, Kamaruzzaman YB, Zaleha K (2010) Mechanism in the clot formation of horseshoe crab blood during bacterial endotoxin invasion. Journal of Applied Sciences 10:1930-1936

23. Kamaruzzaman BY, John AB, Zaleha K, Jalal KCA (2011) Molecular phylogeny of horseshoe crab. Asian J Biotechnol 3:302-309

24. Eldredge N, Stanley SM (1984) Living Fossils. Springer, Berlin

25. Selander RK, Yang SY, Lewontin RC, Johnson WE (1970) Genetic variation in the horseshoe crab (Limulus polyphemus), a phylogenetic relic. Evolution 24:402-414. DOI:10.1111/j.1558-5646.1970.tb01771.x

26. Yang MC, Chen CA, Hsieh HL, Chen CP (2007) Population subdivision of the tri-spine horseshoe crab, Tachypleus tridentatus, in Taiwan Strait. Zool Sci 24:219-224. https://doi.org/10.2108/zsj.24.219

27. Avise JC (2000) Phylogeography. Academic Press, New York, pp 104-106

28. Pierce JC, Tan G, Gaffney PM (2000) Delaware Bay and Chesapeake Bay populations of the horseshoe crab Limulus polyphemus are genetically distinct. Estuaries 23:690-698

29. Mitton JB (1994) Molecular approaches to population biology. Annual Rev Ecol Systemat 25:45-69

30. Saunders NC, Kessler LG, Avise JC (1986) Genetic variation and geographic differentiation in mitochondrial DNA of the horseshoe crab, Limulus polyphemus. Genetics 112:613-627

31. King TL, Eackles MS (2004) Microsatellite DNA markers for the study of horseshoe crab (Limulus polyphemus) population structure. Mol Ecol Notes 4:394-396

32. Nishida S, Koike H (2009) Genetic structure of Japanese populations of Tachypleus tridentatus by mtDNA AT-rich region sequence analysis in Biology and Conservation of Horseshoe Crabs. In: Tanacredi JT, Botton ML, Smith DR (eds) Biology and Conservation of Horseshoe Crab. Springer, New York, pp 183-196

33. Rosel PE, Haygood MG, Perrin WF (1995) Phylogenetic relationship among the true porpoise (Cetacean: Phocoendiae). Mol Phylogenet Evol 4:463-474

34. Hu M, Wang Y, Chen Y, Cheung SG, Shin PKS, Li Q (2009) Summer distribution and abundance of juvenile Chinese horseshoe crabs Tachypleus tridentatus along an intertidal zone in southern China. Aquatic Biology 7:107-112. doi:10.3354/ab00194

35. Sambrook J, Fritsch EF, Maniatis T (1989) Molecular cloning: a laboratory manual. Cold Spring Harbor Laboratory Press, Cold Spring Harbor

36. Gupta SK, Kumar A, Hussain SA (2012) Extraction of PCR-amplifiable DNA from a variety of biological samples with uniform success rate. Conservation Genetics Resources 5:215-217

37. Folmer O, Black M, Hoeh W, Lutz R, Vrijenhoek R (1994) DNA primers for amplification of mitochondrial cytochrome $c$ oxidase subunit I from diverse metazoan invertebrates. Mol Marine Biol Biotech 3:294-299

38. Hall TA (1999) BioEdit: a user-friendly biological sequence alignment editor and analysis program for Windows 95/98/NT. Nucl. Acids. Symp. Ser. 41:95-98

39. Kumar S, Stecher G, Li M, Knyaz C, Tamura K (2018) MEGA X: Molecular Evolutionary Genetics Analysis across Computing Platforms. Mol Biol Evol 35:1547-1549

40. Stamatakis A, Hoover P, Rougemont J (2008) A rapid bootstrap algorithm for the RAxML web servers. Syst Biol 57:758-771

41. Drummond AJ, Rambaut A (2007) BEAST: Bayesian evolutionary analysis by sampling trees. BMC Evol Biol 7:214

42. Drummond AJ, Ho SYW, Phillips MJ, Rambaut A (2006) Relaxed phylogenetics and dating with confidence. PLoS Biol 4:e88

43. Obst M, Faurby S, Bussarawit S, Funch P (2012) Molecular phylogeny of extant horseshoe crabs (Xiphosura, Limulidae) indicates Paleogene diversification of Asian species. Mol Phylogenet Evol 62:21-26

44. Pocock RI (1902) XLII. The taxonomy of recent species of. Limulus The Annals Magazine of Natural History ser 9:256-266

45. Avise JC, Nelson WS, Sugita H (1994) A speciational history of living fossils - molecular evolutionary patterns in horseshoe crabs. Evolution 48:19862001 
46. Knowlton N, Weight LA (1998) New dates and new rates for divergence across the Isthmus of Panama. Proc R Soc Lond B 265:2257-2263. doi:10.1098/rspb.1998.0568

47. Shuster CN Jr (1955) On Morphometric and Serological Relationships within the Limulidae, with Particular Reference to Limulus polyphemus (L.). PhD thesis, New York University, New York (1958 Diss Abstr 18, pp 371-372)

48. Xia XH (2000) Phylogenetic relationship among horseshoe crab species: effect of substitution models on phylogenetic analyses. Syst Biol 49:87-100

\section{Tables}

Table 1. Estimate of genetic diversity in CO/gene among T. gigas samples collected from Odisha.

\begin{tabular}{|c|c|c|c|c|c|c|}
\hline Locality & Coordinates & $\begin{array}{l}\text { Sample } \\
\text { size }\end{array}$ & $\begin{array}{l}\text { Numbers of } \\
\text { Haplotypes }\end{array}$ & $\begin{array}{l}\text { Haplotypes } \\
\text { diversity }(H d)\end{array}$ & $\begin{array}{l}\text { Average number of nucleotide } \\
\text { differences (k) }\end{array}$ & $\begin{array}{l}\text { Nucleotide } \\
\text { diversity }(\pi)\end{array}$ \\
\hline Udaypur & $\begin{array}{l}21.588111 / \\
87.432111\end{array}$ & 7 & 2 & 0.571 & 0.571 & 0.00098 \\
\hline Chaumukh & $\begin{array}{l}21.566375 / \\
87.354022\end{array}$ & 1 & - & - & - & - \\
\hline Chandamani & $\begin{array}{l}21.549633 / \\
87.354022\end{array}$ & 3 & 2 & 0.667 & 0.667 & 0.00115 \\
\hline Kasafal & $\begin{array}{l}21.536691 / \\
87.173719\end{array}$ & 7 & 4 & 0.714 & 1.048 & 0.00180 \\
\hline Bahabalpur & $\begin{array}{l}21.515336 / \\
87.117036\end{array}$ & 12 & 6 & 0.682 & 1.212 & 0.00209 \\
\hline Balaramgadi & $\begin{array}{l}21.470663 / \\
87.071619\end{array}$ & 5 & 2 & 0.400 & 0.400 & 0.00069 \\
\hline Mahisali & $\begin{array}{l}21.409772 / \\
86.979433\end{array}$ & 12 & 6 & 0.818 & 2.848 & 0.00490 \\
\hline Khapara & $\begin{array}{l}21.375544 / \\
86.946691\end{array}$ & 7 & 5 & 0.905 & 2.095 & 0.00361 \\
\hline Khandia & $\begin{array}{l}21.338325 / \\
86.911961\end{array}$ & 76 & 15 & 0.700 & 1.146 & 0.00197 \\
\hline Kantiachira & $\begin{array}{l}21.315407 / / \\
86.893259\end{array}$ & 12 & 6 & 0.864 & 1.636 & 0.00282 \\
\hline Chudamani & $\begin{array}{l}21.141586 / \\
86.786611\end{array}$ & 5 & 3 & 0.700 & 0.800 & 0.00138 \\
\hline $\begin{array}{l}\text { Kanika } \\
\text { Island }\end{array}$ & $\begin{array}{l}20.828744 / \\
86.988291\end{array}$ & 1 & - & - & - & - \\
\hline Dosinga & $\begin{array}{l}20.813338 / \\
86.964961\end{array}$ & 2 & 1 & 0.000 & 0.000 & 0.00000 \\
\hline \multirow[t]{2}{*}{ Chandinipal } & $\begin{array}{l}20.787877 / / \\
86.959363\end{array}$ & 2 & 2 & 1.000 & 2.000 & 0.00344 \\
\hline & & 152 & 26 & 0.578 & 1.175 & 0.00265 \\
\hline
\end{tabular}

Table 2. Variable nucleotide positions within 26 haplotypes of T. gigas.

\section{Figures}




\begin{tabular}{|c|c|c|c|c|c|c|c|c|c|c|c|c|c|c|c|c|c|c|c|c|c|c|c|c|c|c|c|}
\hline \multirow[t]{3}{*}{ Haplotype } & \multirow{3}{*}{$\begin{array}{l}\text { Accession } \\
\text { no. }\end{array}$} & \multirow{3}{*}{$\begin{array}{l}1 \\
8\end{array}$} & \multirow{3}{*}{$\begin{array}{l}2 \\
6\end{array}$} & \multirow{3}{*}{$\begin{array}{l}4 \\
3\end{array}$} & \multirow{3}{*}{$\begin{array}{l}6 \\
0\end{array}$} & \multirow{3}{*}{$\begin{array}{l}7 \\
6\end{array}$} & \multirow{3}{*}{$\begin{array}{l}7 \\
8\end{array}$} & \multirow{3}{*}{$\begin{array}{l}1 \\
0 \\
3\end{array}$} & \multirow{3}{*}{$\begin{array}{l}1 \\
3 \\
8\end{array}$} & \multirow{3}{*}{$\begin{array}{l}1 \\
6 \\
2\end{array}$} & \multirow{3}{*}{$\begin{array}{l}1 \\
7 \\
3\end{array}$} & \multirow{3}{*}{$\begin{array}{l}2 \\
6 \\
2\end{array}$} & \multirow{3}{*}{$\begin{array}{l}2 \\
6 \\
5\end{array}$} & \multirow{3}{*}{$\begin{array}{l}2 \\
7 \\
2\end{array}$} & \multirow{2}{*}{$\begin{array}{l}2 \\
9\end{array}$} & \multirow{2}{*}{$\begin{array}{l}3 \\
3\end{array}$} & \multirow{2}{*}{$\begin{array}{l}3 \\
4\end{array}$} & \multirow{2}{*}{$\begin{array}{l}3 \\
4\end{array}$} & \multirow{2}{*}{$\begin{array}{l}4 \\
2\end{array}$} & \multirow{2}{*}{$\begin{array}{l}4 \\
4\end{array}$} & 4 & 4 & 5 & 5 & 5 & 5 & \\
\hline & & & & & & & & & & & & & & & & & & & & & 5 & 9 & 0 & 1 & 2 & 2 & 3 \\
\hline & & & & & & & & & & & & & & & 5 & 4 & 0 & 6 & 9 & 2 & 3 & 9 & 8 & 9 & 2 & 5 & 6 \\
\hline $\mathrm{H} 1$ & MZ262422 & C & G & C & G & A & $\mathrm{T}$ & G & $\mathrm{T}$ & C & $\mathrm{T}$ & G & G & G & G & G & G & C & $\mathrm{T}$ & G & $\mathrm{T}$ & C & $\mathrm{T}$ & A & $\mathrm{T}$ & C & $\mathrm{T}$ \\
\hline $\mathrm{H} 2$ & MZ262423 & . & . & . & $A$ & . & . & . & . & . & . & . & . & . & . & . & . & . & . & . & C & . & . & . & . & . & . \\
\hline H3 & MZ262424 & . & . & . & . & . & . & . & . & . & . & . & . & . & . & . & . & . & . & . & C & . & . & . & . & . & . \\
\hline $\mathrm{H} 4$ & MZ262425 & . & . & . & . & . & C & . & . & . & . & . & A & . & . & . & . & . & . & . & C & . & . & . & . & . & . \\
\hline H5 & MZ262426 & . & . & . & . & . & . & . & . & . & . & . & . & . & A & . & . & . & . & A & . & . & . & . & . & . & . \\
\hline $\mathrm{H} 6$ & MZ262427 & $\mathrm{T}$ & . & . & . & . & A & . & . & . & . & . & . & . & . & . & . & . & . & . & . & . & . & . & . & . & . \\
\hline $\mathrm{H} 7$ & MZ262428 & . & . & . & . & . & & . & G & . & . & . & . & . & . & . & . & . & . & . & . & $A$ & . & . & . & . & . \\
\hline $\mathrm{H} 8$ & MZ262429 & . & . & . & A & . & . & . & . & . & . & . & . & . & . & . & . & . & . & . & C & . & . & . & . & $\mathrm{T}$ & . \\
\hline $\mathrm{H} 9$ & MZ262430 & . & . & . & . & . & . & . & . & . & . & . & . & . & . & . & . & . & A & . & . & . & . & . & . & . & . \\
\hline H10 & MZ262431 & . & . & . & . & . & . & . & . & . & . & . & . & . & . & . & A & . & . & . & . & . & . & . & . & . & . \\
\hline $\mathrm{H} 11$ & MZ262432 & . & . & . & . & C & . & . & . & . & . & . & . & . & . & . & . & . & . & . & . & . & . & . & . & . & G \\
\hline $\mathrm{H} 12$ & MZ262433 & . & . & . & . & . & . & . & . & . & . & . & . & . & . & . & . & . & . & . & . & . & . & G & . & . & . \\
\hline H13 & MZ262434 & . & . & . & A & . & . & . & . & . & . & . & . & . & . & . & . & . & . & . & C & . & C & . & . & . & . \\
\hline $\mathrm{H} 14$ & MZ262435 & . & . & . & . & . & . & . & . & $\mathrm{T}$ & . & . & . & . & . & . & . & . & . & . & . & . & . & . & . & . & . \\
\hline H15 & MZ262436 & . & . & . & A & . & . & A & . & . & . & . & . & . & . & . & . & . & . & . & $\mathrm{C}$ & . & . & . & . & . & . \\
\hline H16 & MZ262437 & . & $\mathrm{T}$ & . & . & . & & . & . & . & . & . & . & . & . & . & . & . & . & . & . & . & . & . & . & . & . \\
\hline H17 & MZ262438 & . & $\mathrm{T}$ & . & & & . & . & . & . & . & . & A & . & . & . & . & . & . & . & C & . & . & . & . & . & . \\
\hline H18 & MZ262439 & . & . & . & . & . & & . & . & . & . & A & . & . & . & . & . & . & . & . & . & . & . & . & . & . & . \\
\hline H19 & MZ262440 & . & . & . & . & . & . & . & . & . & . & . & . & . & . & . & . & . & . & A & . & . & . & . & . & . & . \\
\hline $\mathrm{H} 20$ & MZ262441 & . & . & . & . & . & . & . & . & . & . & . & . & $A$ & . & . & . & . & . & . & . & . & . & . & . & . & . \\
\hline H21 & MZ262442 & . & . & . & A & . & . & . & . & . & . & . & . & . & . & . & . & . & . & . & . & . & . & . & . & . & . \\
\hline $\mathrm{H} 22$ & MZ262443 & . & . & $\mathrm{T}$ & . & . & . & . & . & . & . & . & . & . & . & A & . & . & . & . & . & . & . & . & . & . & . \\
\hline $\mathrm{H} 23$ & MZ262444 & . & . & . & A & . & . & . & . & . & . & . & . & . & . & . & . & $\mathrm{T}$ & . & . & C & . & . & . & . & . & . \\
\hline $\mathrm{H} 24$ & MZ262445 & . & . & . & . & . & & . & . & . & . & . & . & . & . & . & . & . & . & . & C & . & . & . & A & . & . \\
\hline $\mathrm{H} 25$ & MZ262446 & . & . & . & . & . & & . & . & . & . & . & A & . & . & . & . & . & . & . & C & . & . & . & . & . & . \\
\hline $\mathrm{H} 26$ & MZ262447 & . & & . & $A$ & & . & . & . & . & A & . & . & . & . & . & . & . & . & . & $\mathrm{C}$ & . & . & . & . & & . \\
\hline
\end{tabular}




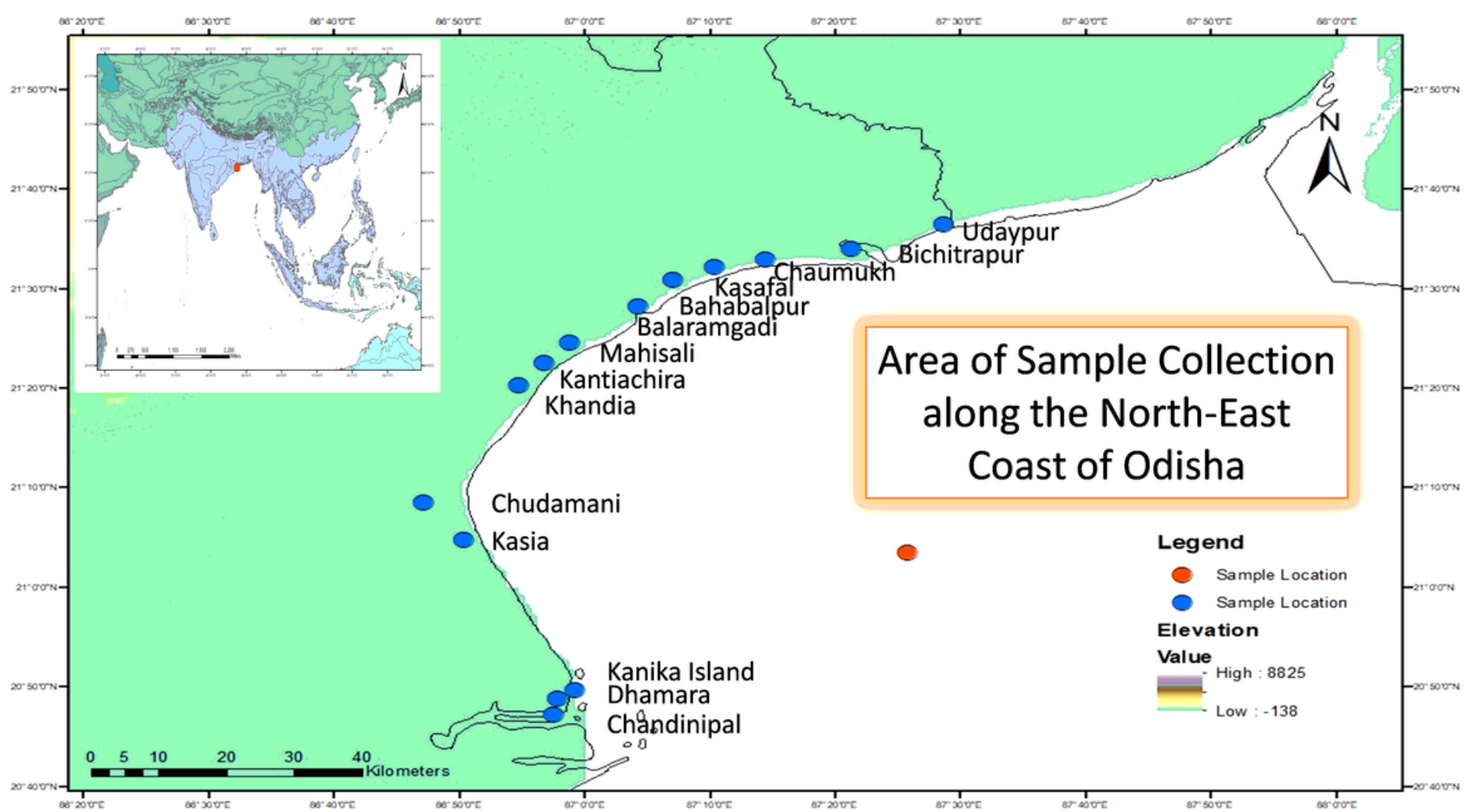

Figure 1

Location of 14 sampling sites along the coast of the Bay of Bengal in Balasore District, Odisha. Note: The designations employed and the presentation of the material on this map do not imply the expression of any opinion whatsoever on the part of Research Square concerning the legal status of any country, territory, city or area or of its authorities, or concerning the delimitation of its frontiers or boundaries. This map has been provided by the authors.

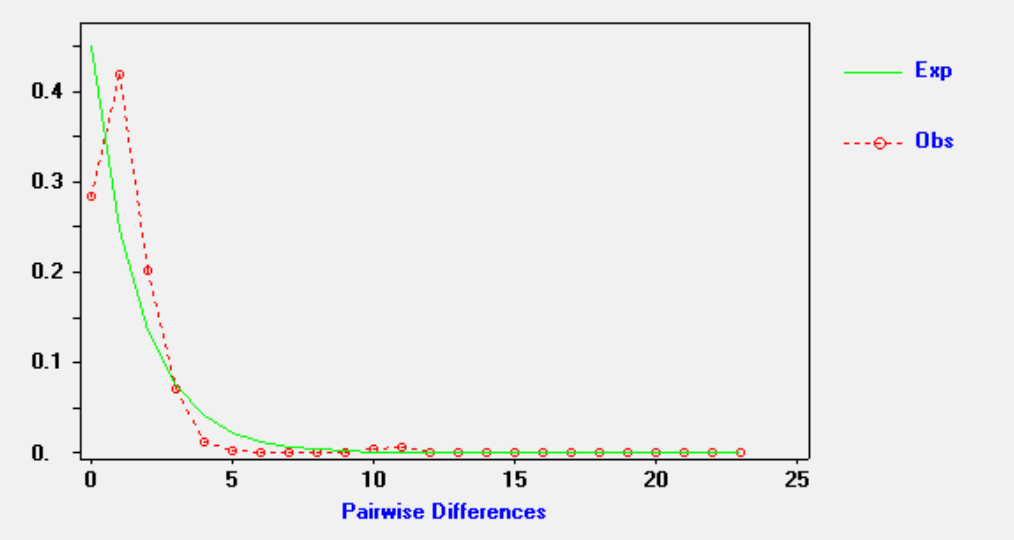

Figure 2

Demographic parameters estimated from COI gene sequences for horseshoe crabs population in India. Mismatch analysis of 26 haplotypes of the horseshoe crab. 


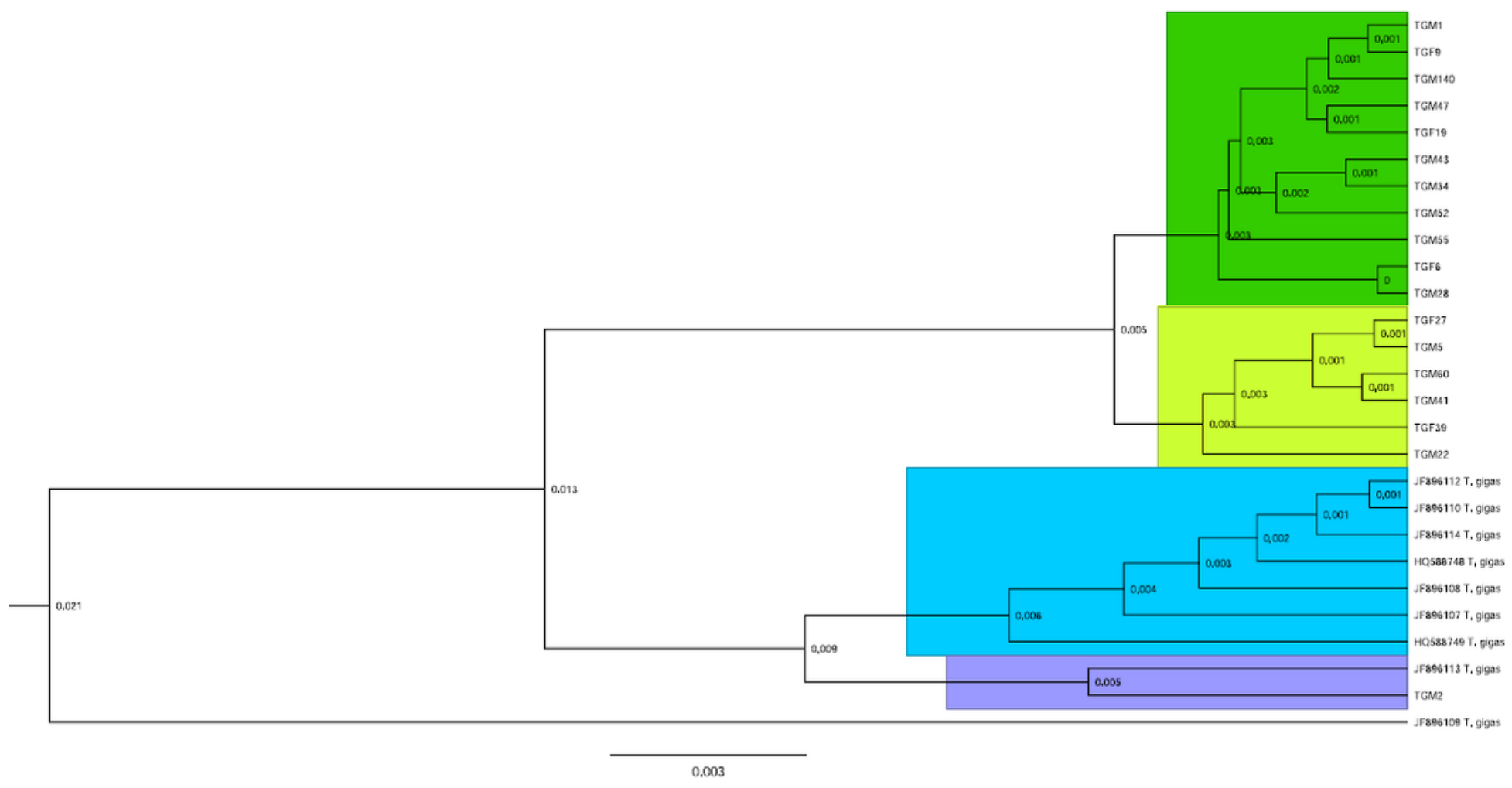

Figure 3

Phylogeographic tree for the COI fragment. The color represents the localities.

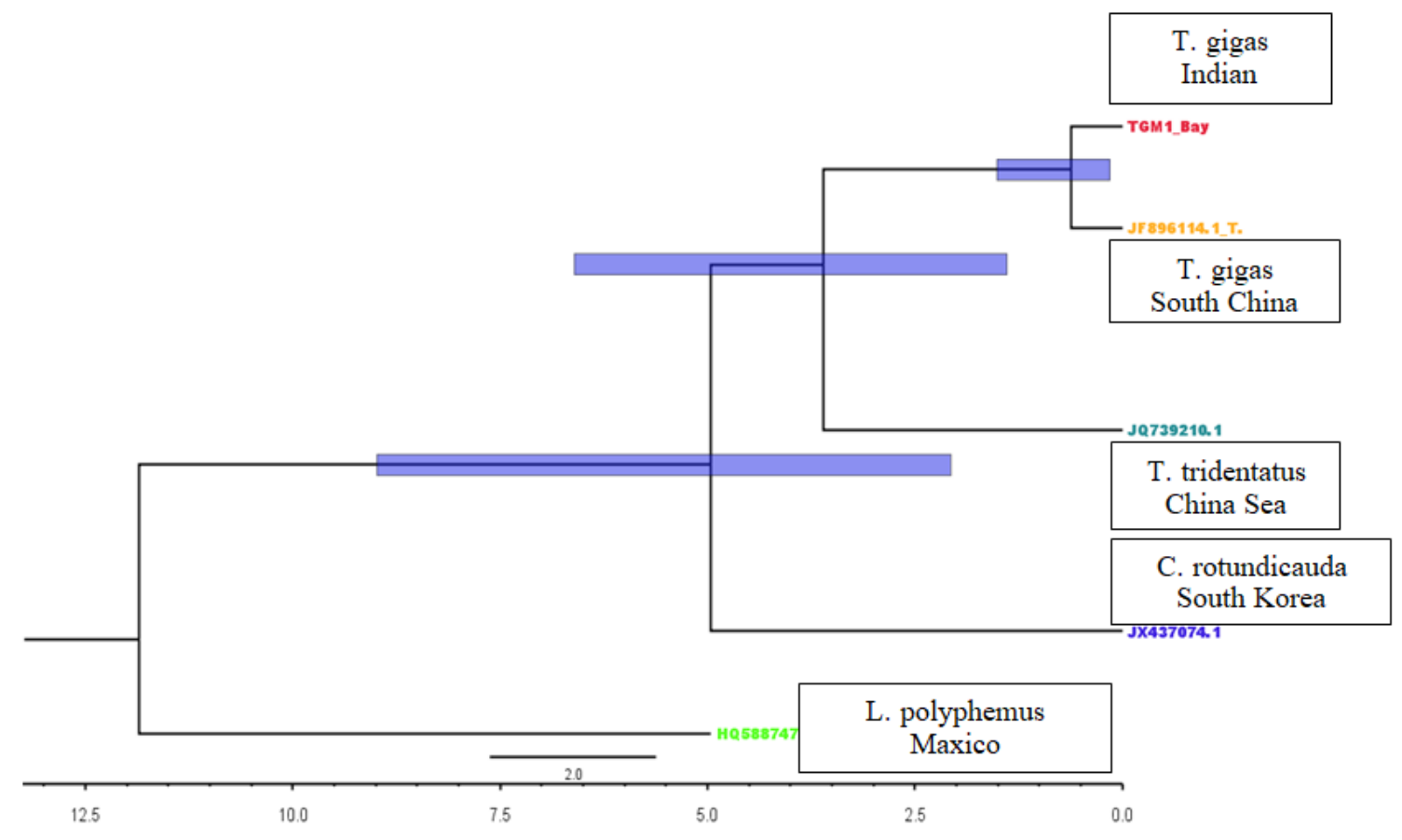

Figure 4

Chronogram based on the BEAST divergence time analysis showing the estimated evolutionary radiation of Asian horseshoe crabs. Blue bars indicate $95 \%$ confidence levels. The times scale below the chromatogram features all major geological periods in Mya. 